\title{
The Nigerian Contributory Pension Market: A Review of Compliance Status across the Federation
}

\author{
Cosmas Ogobuchi Odo', Christopher Chukwudi Orga ${ }^{2}$, Kenneth C. Ozoemenam ${ }^{3}$ \\ ${ }^{1}$ Department of Marketing, Enugu State University of Science and Technology, Enugu, Nigeria \\ ${ }^{2}$ Department of Business Administration, Enugu State University of Science and Technology, Enugu, Nigeria \\ ${ }^{3}$ Social Policy Specialist, United Nations Children's Fund (UNICEF), Enugu, Nigeria \\ Email: cosmasudoka@yahoo.com,chrisorga@yahoo.com, kozoemenam@gmail.com
}

How to cite this paper: Odo, C. O., Orga, C. C., \& Ozoemenam, K. C. (2019). The Nigerian Contributory Pension Market: A Review of Compliance Status across the Federation. Journal of Financial Risk Management, 8, 163-176.

https://doi.org/10.4236/jfrm.2019.83011

Received: July 12, 2019

Accepted: August 27, 2019

Published: August 30, 2019

Copyright (C) 2019 by author(s) and Scientific Research Publishing Inc. This work is licensed under the Creative Commons Attribution International License (CC BY 4.0).

http://creativecommons.org/licenses/by/4.0/

\begin{abstract}
The paper reviews the compliance status of the Federal, State and private sector pension systems in Nigeria after the reform in 2004 that changed the funding strategy from pay-as-you-go to the contributory modality. It first spotlighted the grim factors of the old pension system that made reform inevitable. The paper in the main argues that compliance with the provisions of the law remains the only guarantee of workers' retirement future. It further points out the specific role labour leadership must play in this regard. The paper disclosed that the observed failure to implement the provisions of the law across the tiers, especially the federal and state government segments, arose in part due to a conspiracy of factors, including, recession, legislative loopholes, supervisory negligence, and absence of sustained engagement of labour leadership with employers across the tiers. The paper therefore concludes by recommending a more focused engagement strategy by labour leadership and a stricter penalty that makes default in making contributions less attractive.
\end{abstract}

\section{Keywords}

Pay-As-You-Go, Pension, Political Risks, Compliance, Guaranteed Minimum Pension

\section{Introduction}

Nigeria implemented a pension reform in 2004. The reform switched her pay-as-you-go run public pension scheme to a contributory regime. The new pension scheme owes its origin to the need to bequeath Nigerians an entirely 
new pension market that not only procures pension for both private and public sector workers but guarantees a framework that delivers regular pension income for retired workers. In the years prior to the passage of the Contributory Pension Act, 2004 (now repealed and replaced by Pension Act, 2014), pension administration in Nigeria had proved largely chaotic and unsustainable (Binuomoyo, 2009; Inabo, 2011; Oloja, 2011). As at 2005, the pension debt in the public nation-wide was $\mathrm{N} 2$ trillion (FGN, 2005). The crisis reflected mainly in huge pension arrears, delay in release of budgetary allocations, cumbersome pension delivery system, inaccurate data base for pensioners and alleged cases of pension-related fraud (Inabo, 2011; Oloja, 2011; Binuomoyo, 2009). This was the background before the passage of the Act, which has clearly articulated objectives namely, ensuring that every person who worked in either the public service of the Federation, Federal Capital Territory or the private sector receives his retirement benefits as and when due; assisting improvident individuals by making sure that they save to cater for their livelihood during old age (poverty-reducing objective) and establishing a uniform set of rules, regulation and standards for the administration and payment of pension benefits for the public service of the federation, Federal Capital Territory and the private sector (The National Assembly, 2004).

The Pension Act, being a Federal law, has a restrictive application to Federal Ministries, Departments and Agencies (MDAs) and does not in any way imply an automatic application across states. To be operational in the states, the State Houses of Assembly must take steps to adopt and domesticate the Federal Law on pension. In fact, the Act in section 23(i) inserts that "one of the functions of the Regulatory Agency, the National Pension Commission (PenCom), includes promoting and offering technical assistance in the application of the contributory pension scheme by the States and the Local Government Councils in accordance with the objectives of this Act". Clearly the Federal law places no more than persuasive influence on the states and local councils for its adoption and compliance.

The scheme has been in operation for twelve years post inauguration. It may have become necessary to carry out a post-mortem examination of the new pension regime for two main reasons. The first issue relates to the usual policy implications of pension matters especially their emphasis on poverty reduction among the ranks of the retirees. Hence an urgent quest seems to have arisen to uncover what the score card shows for each state in the Federation in connection with the adoption and domestication of the new pension law. As is self-evident, failure to enthrone a regime of functional and sustainable pension market in the states is a recipe for encouraging poverty at old age. This inquiry is even more compelling now given the unpleasant records that show that some states owe their workers accumulated salaries and pension arrears (Egbuna, 2018; Gbolangute, 2018). The second reason rests on the expectation that the exercise when completed will not only enhance citizens' mental and optic appreciation of pension market as it stands but would aid Leadership of Labour Unions in Nige- 
ria in the discharge of its constitutional role of catering for the welfare of workers, in service or in retirement.

D'Arcy et al. (1999) have opined that few literature exists that inquire into pension matters. It remains an under researched field. Studies on the Nigerian pension market have only just begun to gather steam and take roots. Few have pried into its depth. For instance, Umar and Emmanuel (2012) looked at contributory pension as a tool for economic growth in Nigeria. The study found a link between pension fund investment and the growth in GDP. Akpa and Ukpong looked at pension administration and capital formation in Nigeria. The study found that contributory pension led to growth and the development of the capital market in Nigeria. Njuguno, 2010 in Umar and Emmanuel (2012) claims that pension funds contribute to GDP, accumulation of savings and financial market development. The rest of the paper shall be taken in the following order.

\section{Undesirable Features of the Old Pension Market in Nigeria}

The Old pension market in Nigeria which was essentially non-contributory depended on government's budgetary allocations for its funding (Okafor, 2000). It was a variant of the traditional pay-as-you go funding modality. The pay-as-you-go system had created huge crises on a global scale which laid the foundation for insistent demand for reform especially the public sector segment of the market (The World Bank, 1994). The Nigeria pension market, in particular, was afflicted by some undesirable features that rendered a shift to the contributory status inevitable. These features are examined next.

1) Stranglehold of Corruption on the Public Sector Pension Market. Corruption, in its various manifestations, is a leech that gnaws at the soul of Nigerian State. At a time the nation was ranked as the second most corrupt countries in the world (Uche, 1998). Corruption showed itself in the old pension management via, insertion of fictitious pensioners, delay in payment of pension because officers in charge chose to keep pension money in banks to earn interest for themselves, under-payments of actual pension due and outright diversion of pension funds for personal enrichment by top government officials or pension office staff. It was the desire to save the pension system in Nigeria from further decay that culminated in the reform that was put in place in 2004.

2) Slowness of Pension Disbursement Process. A weakness of the public sector pension system also showed in the way senior citizens were treated. It was common to observe how decrepit elderly citizens were compulsorily required to travel long distances to the point of pension payment. Worse still, they were left under inclement weather, for long hours and sometimes for days before collecting their stipends. Some pensioners were claimed to have died while standing in a queue waiting to receive pension money (Ovuorie, 1998). This could only mean deficiency of ideas or unwillingness to deploy ideas in the way pension payment should be handled. The contributory pension system however has reduced these flaws, although occasional biometric verification of pensioners is 
still required.

3) The Financing Method. The old pension system before reform slipped into deep crisis, with very huge pension arrears that created economic hardship to pensioners. Method of funding was a key factor in this crisis. Civil servants, prior to Pension Reform Act of 2004, made no personal sacrifices by way of payroll levies, for provision of pension. Pension benefits, instead, were paid through budgetary allocations that were kept in the Consolidated Revenue Fund (Okafor, 2000). By its nature budgets are estimates of revenues and expenditures for the fiscal years concerned. As happens, it is entirely possible that the amount released for pension payment differs from actual appropriation for pension payment. For instance, in fiscal year 2001, N6.4b was needed for payment of military pensions but only N2.1b was released for Defence, leaving a balance of N4.3b pension arrears (Onuorah, 2002).

The mounting pension debts in the old public sector pension market stemmed from the status of the pre-reform pension system: funding was made via budgetary allocations; this more often than not ran short of funds for pension debts. Many of these systems, namely, schemes of the civil service, parastatals and universities owed arrears of pension, for months and sometimes years. The NEWS (2002) claimed that between 1995 and 1999 the budgeted federal expenditure on remuneration of federal employees increased five folds, whereas the budgeted expenditure on pension and gratuities increased ten folds. This paucity of funds for pension debts is what is being tackled by the contributory pension scheme.

4) Public Sector Pension's Exposure to Political Risks. It has been argued that social security pensions provided on the basis of pay-as-you-go are subject to political risks (Davis, 1993; Diamond, 1996). The risks manifest in three forms. The first relates to the brazen disposition of politicians who for political reasons do offer fabulous pension increases that they are either not prepared to honour or which may fall due long after they have left office. The second aspect of the risk refers to the fact that the pension account, in not being distanced from political control, falls easy "prey" to politicians who divert pension funds to cushion temporary fiscal shocks. The third relates to the socio-political indifference of politicians to the plight of pensioners. The current never-ending debate on minimum wage for Nigerian workers highlights this callous indifference, even on the eve of an election year (Ego-Alowes, 2018). Whereas Labour Union asked for a paltry N30000 monthly salary government claimed to be prepared to concede N24000 (Bello, 2018). The fate of pensioners can only be imagined if the requests of workers were scornfully treated. All of these risks seem fully played out in the public sector pension management in Nigeria. These are however adequately being tackled, hopefully, by the current pension market as shall be disclosed when we discuss the second part of the paper.

5) Pension Default by State Governments. Furthermore, it was also claimed that pension debts in the public sector mounted, in part, because of the failure of some state governments to provide their counterpart funds necessary to make up the amount provided by the federal government, in situations where the affected 
pensioners worked for both federal and state governments. As a rule, further release of money by the Federal Government to the State government could only happen on proven evidence that pension for the previous month had been settled. This seems to explain why a State would fail to collect federal government counterpart funds, for months, because the States affected could show no evidence of being up to date in payment of pensions.

6) Pension Records Flaws. The way record of pensioners in the public sector was kept created avoidable problems. In some establishments no accurate record of actual pensioners existed. Corruption breeds more in the absence of facts and figure. This claim was dramatized in bold relief when verification of military pension account led to the discovery of 23,000 fake pensioners on the Army pension roll (Uwujaren, 2004). This account agrees largely with Uzoma (1993) who once disclosed that pension costs in the public sector were inflated through insertion of fictitious names on the list of pensioners.

\section{The Desirable Features and Safeguards of the Contributory Pension System}

The account above reflects both the picture of the old pension market in Nigeria and the factors that compelled its reform in 2004. Aware that the old pension system has proved unsustainable, government passed the pension reform Act of 2004 which made pension provision in the public and private sectors contributory. There are certain features and safeguards of the new pension regime which offer a hint of bright prospects for the scheme. They are examined below.

\subsection{Features}

1) Individual Retirement Savings Account. The law allows every employee to open and maintain a savings account in his name with any pension fund administrator of his choice. In sec 11(1) of 2004 Act, the law provides that every employee shall maintain an account (in this Act referred to as "retirement Savings account") in his name with any pension administrator of his choice. In practice, however, this choice is made on group basis working through the labour unions or by the employer himself. This is usually so done for administrative and cost considerations. It would be rather cumbersome and cost-ineffective to have to deal with several pension administrators serving several workers within the same ministry or establishment. It is noteworthy that the individualized savings account system of the scheme helps to remove pension from political control of the employer. More importantly, the savings account for each worker is portable. Specifically, section 13 of the Act, provides a window for a transfer of account for a worker who switches from one employer to another. The tenor of the law reads thus "Where an employee transfers his service or employment from one employer or organisation to another, the same retirement savings account shall continue to be maintained by the employee". In fact, it is possible to switch from one pension administrator to another by a worker who is in search of a superior account performance provided that this does not happen 
more than once a year (see Section 11 Subsection 2 of the Act, 2004). On balance, these provisions frontally tackle the political risks of old pension market in the public sector.

2) Pension Fund Administrators (PFAs). Licensed PFAs are to open retirement savings account for employee, invest and manage the funds in fixed income securities and other instruments as may be determined by the Regulatory Agency, the National Pension Commission (PENCOM). Some of the specific functions of the PFAs, as specified in section 45 of the Act, include but not limited to, opening retirement savings account for all employees with a Personal Identity Number (PIN); investing and managing funds and assets in accordance with provisions of this Act; maintaining books of account on all transactions relating to pension funds managed by it and provision of customer service support to employee, including access to employees account balances and statement on demand. This provision could enthrone a regime of efficiency and transparency in pension administration process provided that the PENCOM lives up to its statutory role.

3) Pension Assets Custodians (PACs). As enshrined in the law, these licensed entities warehouse pension fund assets. Whereas the PFAs carry out investment functions, the PACs keep custody of funds assets. The arrangement provides checks and balances in the pension administration process. Relevant functions of PACs as specified in section 47 of the Act include the following among others, receiving of the total contributions remitted by the employer on behalf of the pension fund administrator within four hours of such receipt from any employer; notification of the PFA within 24 hours of the contributions from any employer; holding pension funds and assets in safe custody on trust for the employee and beneficiaries of the retirement savings account; settlement of transactions, on behalf of PFA, and undertaking of activities relating to the administration of pension fund investments including collection of dividends and furnishing reports to PENCOM on matters that relate to the assets being held by it on behalf of any pension fund administrator at such intervals as may be determined by the regulator.

4) The National Pension Commission (PENCOM). This is the regulatory body that regulates and ensures the smooth functioning of the entire pension market. As sections 57 and 79 of Act, 2004 clearly show, the Commission employs both on-site and off-sit regulatory and supervisory measures in the discharge of its oversight functions. The off-site supervisory strategy relates to the mandatory annual reports of operations of both the PFAs and PFCs that must be submitted to the regulator. The Act in section 57 is unambiguous in stating that "the pension fund administrator or custodian shall not later than four months from the end of the financial year submit to the Commission an annual report of the immediate preceding year on the pension funds being managed by him and such report shall include audited accounts". From the report it is easy to gauge the compliance or violations of the provisions of the Act by these entities. On the other hand, on-site regulatory approach refers to the powers of the regulator 
under the Act to visit either the pension fund administrator or custodian and demand access to the books of account of the entities and perhaps a verification of assets as may have been claimed in the annual report. As sometimes happens, there could be differentiations between book values and physical material assets. Supervisory visits help to clear things up.

5) Retirement Benefits Bond Redemption Fund. The law provides for a retirement benefits bond redemption fund to be maintained by the Central Bank of Nigeria (CBN). The fund takes care of the transition financing gap created by the switch from pay-as-you-go to a funded system. The Federal Government is to credit it with an amount equal to 5\% of the total monthly wage bill of federal workers. The fund is to settle the implicit pension debt in the old scheme. The said financing gap refers to the pension rights which workers have earned under the old pay-as-you-go system up to the time they migrate to the contributory pension scheme. These rights earned up to the time of introducing the contributory pension scheme had remained unfunded. And since these rights have to be paid for at the time these workers retire the law provides that these deficits be provided for by issuance of redemption bonds. The face value of the bond for each worker (the maturity date of bond tallies with pension rights earned up the time of switch for each worker) shall be paid into retirement savings account at the point of disengagement.

\subsection{Scheme Safeguards}

There are certain safeguards that define the operation of the new pension market. The first relates to the separation of functions between PFAs and the PACs. Their roles do not overlap given that the PFA does not have custody of the contributions of employees nor does the custodian invest but to the order of the PFA. Again, in view of the large assets a custodian is expected to handle, the law mandates him to issue a guarantee in the full sum of the assets it holds. To further inspire confidence in the scheme, government's contribution is made a first charge on the consolidated Revenue Fund of the Federation. Besides, both the 2004 and the 2014 pension Acts, provide for the payment of Guaranteed Minimum Pension, through creation of Pension Protection Fund. This is for all retirement savings account holders who have contributed for a number of years to a licensed pension fund administrator. The protection fund comes handy where their savings prove inadequate or in cases of insolvency of the pension fund administrator. However, it is only the 2014 Act that stipulates how the funds for the payment of minimum pension should be built up and who should be charged with that responsibility. Hence, section 82 (1-4) of Pension Act, 2014 provides as follows: "The Commission shall establish and maintain a fund to be known as the Pension Protection Fund for the benefits of eligible pensioners covered by any pension scheme established, approved or recognised under this Act". The Pension Protection fund shall consist of, an annual subvention of $1 \%$ of the total monthly wage bill payable to employees in the Public Service of the Federation towards the funding of the minimum guaranteed pension; annual 
pension protection levy paid by the Commission and all licensed pension operators at a rate to be determined by the Commission from time to time and income from investment of Pension Protection Fund. The Commission shall utilise the Pension Protection Fund for: the funding of the minimum guaranteed pension pursuant to the section 84 of this Act; the payment of compensation to eligible pensioners for shortfall or financial losses arising from investment activities and any other purpose deserving protection with the Pension Protection Fund as the Commission may determine from time to time. It may be necessary to add that in 2014 Act the contribution rate has been slightly reviewed upward. In the 2004 Act, both the employee and employer were required to make equal contribution to the scheme at the rate of a minimum of $7.5 \%$ of the monthly emoluments of the employee, making a total contribution rate of $15 \%$ (Section 9 (1) i \& ii). The 2014 Pension Act stipulates a minimum contribution rate $10 \%$ for the employer and $8 \%$ of contribution for the employee, bringing it up to a total contribution rate of $18 \%$. Furthermore, and as a departure from the past, the 2004 Act was silent on the treatment of university professors and other such cadre of government employees who are entitled to the payment of their full salary as pension on retirement. In the 2014 pension Act, Section 7, Subsection 1 (d) \& (e), provides that "professors covered by the Universities (Miscellaneous Provisions Amendment) Act, 2012 shall be according to the University Act; or other categories of employees entitled, by virtue of their terms and conditions of employment, to retire with full retirement benefits shall still apply".

\section{Gauging the Compliance Level in the Implementation of the Contributory Pension Scheme in Nigerian Market}

This part of the paper reviews the extent to which the provisions of the pension provisions are being implemented at the Federal, the state and the private sector tiers of the contributory pension market. In each case, the paper looks at some specific, core provisions of the law and tries gauging the extent to which they are followed or violated. The position of the paper is that the success of the scheme at all tiers is closely tied to the extent of compliance with the provisions of the law. The second part of the assignment takes up a panoramic tour of the states in order to discover how they stand with regard to the adoption and domestication of contributory pension scheme through appropriate legislations. Compliance with the specific provisions of the Act in the states is secondary to its adoption.

On a general note, Nweke (2017) observed that there have been some challenges facing the implementation of the federal pension law. According to him, the Federal Government, since the economy slipped into recession, found itself in an awkward position such that it could not fund fully its pension liabilities. Because of the reduced revenue accruing to government, it could not meet up with its statutory transfer of $5 \%$ of total wage bill that is meant to build up the Redemption fund Account (Nweke, 2017). This is the fund that is designed to absorb the accrued pension rights of workers who transfer from the pay-as-you-go pension system to the contributory scheme. This development may explain in 
part the worrisome concern of retirees who discovered only after retirement that their monthly contributions were never transferred to their PFAs by their employers (Uzoh \& Anekwe, 2018). This point is further supported by the evidence gleaned from the quarterly reports of National Pension Commission (PENCOM) for 2016, 2017 and 2018 respectively. Key issues of concern as highlighted in the compliance reports include, un-credited pension contributions, delay in payment of retirement benefits and outstanding commitments as gleaned from previous routine examinations (Pencom, 2016, 2017, 2018). A major concern of un-remitted and un-credited pension contributions includes the foregone opportunities to grow the individual pension accounts for contributors and the aggregate shortfall in the growth of the pension industry. Although the Commission embarked on some fruitful strategies aimed at recovery of pension debt and associated penalties, it is doubtful the penalties imposed by law were severe enough to deter future relapse. To execute its debt recovery strategy, the Commission engaged the services of private recovery Agents (Pencom, 2016). In 2016, 45 employers had remitted a debt of N775.60 m during the third quarter. As at the end of fourth quarter of 2017, N2.3 m was recovered by the Agents. This brought the total recovery from inception in 2012, to $\mathrm{N} 13.7 \mathrm{~m}$, representing principal contribution of $\mathrm{N} 6.9 \mathrm{~m}$ and penalty of $\mathrm{N} 6.7$ respectively (Pencom, 2017). Again in 2018, first quarter recovery accounts show that a total N7.16b principal contribution outstanding and $\mathrm{N} 6.85 \mathrm{~b}$ in penalty were made. On balance, it could be argued that for employers to hold onto both principal and penalty un-remitted until compelled to do so only suggests that the legal loophole, created by inconsequential penalty, allows a convenient and cheap source of credit to the employers. This loophole, it seems, employers have been exploiting through default. This is hardly debatable given that current market lending rate in Nigeria could go as high as $35 \%$. Meanwhile the law prescribes a minimum of $2 \%$ interest penalty for each month on the amount of unremitted pension deductions (Section 7, Act, 2014).

In Section 9 (3) of 2004 Pension Reform Act, the law specifies that employers shall maintain life insurance policy in favour of the employee for a minimum of three times the annual emolument of the employee. These authors could not source any documentary evidence that could suggest the extent to which Federal Government Ministries, Departments and Agents (MDAs), comply with this provision of the Act. A plausible hint of compliance with this provision could readily have been reflected in increased activities in the life departments' of insurance industry. A couple of telephone interviews with industry operators however confirmed that compliance was more in breach than practice for the national government. The record was worse for the sub national governments as evidence soon bears out. The grave implication of these violations is that the Federal workers are routinely being short-changed by the very government that should care for them. Government workers die without life insurance covers that guarantee death benefits for their dependants. This negates the goal of the law. This is one challenge that the Labour Leadership in Nigeria should look into and 
urgently too.

As earlier pointed out, the compliance level in the states of the Federation paints a dire picture for the future of Nigerian workers. Between 2016 and 2018 there have been marginal increases in the number of states that adopted contributory pension scheme (Pencom, 2016, 2017, 2018). There were observed variations in the degree of implementation across the states. For instance, some states have commenced with just a passage of the state pension law and no more; others not only have enacted the enabling laws but have commenced transfer of contributions to appropriate PFAs; others still, have both passed the law and commenced transfer of remittances, but have also funded the accrued pension rights under the pay-as-you-go scheme; while few others achieved distinction by having procured group life covers as required by the Act (Pencom, 2016, 2017, 2018).

Table 1 depicts how each state in the Federation stands with respect to migration from the pay-as-you-go pension scheme to the contributory pension scheme following the passage of the Pension Reform Act of 2004, as amended by the Act of 2014. As has been stated, the pension law is a federal law. To be applicable in the states, each state House of Assembly has to initiate and pass an equivalent Act to make the contributory pension operational in the given state(s). The table above shows states that have passed equivalent pension Act and those which have not. From the table, only 12 states (33.3\%) out of 36 states have passed the contributory pension law and therefore have commenced making monthly contributions towards payment of pension. Furthermore, only 4 states out of 36, provided Group life insurance cover for workers for the period. Life insurance cover for each worker is a compulsory part of the pension law. There is therefore a gross failure to implement the provisions of the law as regards provision of life insurance covers.

Gadzama (2017) aptly captured the growing trend of the organised private sector participation in the contributory pension scheme when she averred that there had been significant increase in the number of states and organisations keying into the scheme, thereby deepening the pension fund asset and expanding the coverage of the contributory pension scheme. It is argued by some that a key factor in the growth of private sector participation is not unconnected with mandatory presentation of compliance certificates as a pre-condition to bid some Federal Government jobs (Akin-Fadeyi \& Prochazka, 2016). For instance, pension compliance certificate is a prerequisite to access the $\mathrm{CBN}$ intervention fund of N220b to MSME and N140b for market women and farmers (Gadzama, 2017). The results of quarterly reviews of compliance released by the National Pension Commission for specific quarters of 2016, 2017 and 2018, are in the main supportive of the high growth hypothesis of the private sector participation in the CPS. For instance, the Commission issued 3374 organisations with compliance certificates. The organisations remitted a total of $\mathrm{N} 12.19 \mathrm{~b}$ in contributions to the staff RSAs (Pencom, 2016). In the fourth quarter of 2017, certificates of compliance were issued to 13,592 private organisations; the sum of N73, 
Table 1. Level of compliance with the CPS by state government.

\begin{tabular}{|c|c|c|c|c|}
\hline$S / N$ & State & Remittance of Contribution & $\begin{array}{l}\text { Accrued } \\
\text { Rights }\end{array}$ & $\begin{array}{l}\text { Group Life } \\
\text { Insurance }\end{array}$ \\
\hline 1 & Jigawa & $\begin{array}{l}\text { Assets transferred to } \\
6 \text { PFAs for management }\end{array}$ & N/A & N/A \\
\hline 2 & Lagos & Commenced & Funded & Implemented \\
\hline 3 & Ogun & Commenced & Funded & Not implemented \\
\hline 4 & Kaduna & Commenced & Funded & Not implemented \\
\hline 5 & Niger & Commenced & Funded & Implemented \\
\hline 6 & Delta & Commenced & Funded & Not implemented \\
\hline 7 & Zamfara & Commenced & Not Funded & Not implemented \\
\hline 8 & Osun & Commenced & Funded & Implemented \\
\hline 9 & River & Commenced & Funded & Implemented \\
\hline 10 & Kano & Assets yet to be transferred & N/A & N/A \\
\hline 11 & Imo & $\begin{array}{l}\text { Yet to commence remittance } \\
\text { of pension contributions } \\
\text { but the Imo State University } \\
\text { is currently implementing } \\
\text { the CPS under the } \\
\text { auspices of the PRA } 2014\end{array}$ & Not funded & Not implemented \\
\hline 12 & Kebbi & Commence & Not funded & Not implemented \\
\hline 13 & Sokoto & Yet to commence & Not funded & Not implemented \\
\hline 14 & Ekiti & Yet to commence & Not funded & Not implemented \\
\hline 15 & Kogi & Yet to commence & Not funded & Not implemented \\
\hline 16 & Bayelsa & Yet to commence & Not funded & Not implemented \\
\hline 17 & Nasarawa & Yet to commence & Not funded & Not implemented \\
\hline 18 & Oyo & Yet to commence & Not funded & Not implemented \\
\hline 19 & Katsina & Yet to commence & Not funded & Not implemented \\
\hline 20 & AkwaIbom & Yet to commence & Not funded & Not implemented \\
\hline 21 & Edo & Yet to commence & Not funded & Not implemented \\
\hline 22 & Ondo & Commence & Not funded & Not implemented \\
\hline 23 & Benue & Yet to commence & Not funded & Not implemented \\
\hline 24 & Kwara & Yet to commence & Not funded & Not implemented \\
\hline 25 & Plateau & Yet to commence & Not funded & Not implemented \\
\hline 26 & Cross River & Yet to commence & Not funded & Not implemented \\
\hline 27 & Anambra & Commence & Funded & Not implemented \\
\hline 28 & Enugu & Yet to commence & Not funded & Not implemented \\
\hline 29 & Abia & Yet to commence & Not funded & Not implemented \\
\hline 30 & Ebonyi & Yet to commence & Not funded & Not implemented \\
\hline 31 & Taraba & Yet to commence & Not funded & Not implemented \\
\hline 32 & Bauchi & Yet to commence & Not funded & Not implemented \\
\hline 33 & Borno & Yet to commence & Not funded & Not implemented \\
\hline 34 & Gombe & Yet to commence & Not funded & Not implemented \\
\hline 35 & Yobe & Yet to commence & Not funded & Not implemented \\
\hline 36 & Adamawa & Yet to commence & Not funded & Not implemented \\
\hline
\end{tabular}

Source: PenCom quarterly returns for $1^{\text {st }}$ quarter, 2018. 
965,054, 762.47 was channelled into the staff RSAs. In the first quarter of 2018, 4634 organisations were issued with compliance certificates. The sum of N48.94b was remitted to the RSAs (Pencom, 2018). Pencom (2018) pointed out that some private sector organisations were denied clearance certificate of compliance because they did not provide satisfactory evidence of group life insurance for workers. Overall, it could be inferred that compliance level within the private sector organisations has been encouraging. However, researchers could not measure precise rate of such compliance. No universe of such organisations exists.

\section{Findings \& Conclusion}

The paper observes that compliance with the provisions of the law has been more in breach than in practice for the MDAs at the Federal and the State tiers. In particular it was discovered that only twelve (12) states had migrated to the contributory pension scheme. This represents $33.3 \%$ of the population. This record is abysmal given the huge mess the pension system had been enmeshed before the emergence of the contributory pension. It was also observed that most organisations at Federal, State and private sector tiers did not procure life insurance covers for workers in accordance with provisions of the law. It was revealed that only four (4) states, from among those that have passed the pension law, secured life insurance policies for its workers. It could be argued that part of the reasons for poor compliance records at the Federal and State tiers of the pension market could not be unconnected with the recession that hit the nation, beginning in 2016. This arguably affected the revenue profile of both the national and sub-national governments, given its dependence on oil revenue. As revenue dwindled, salaries were not paid and so contributions to RSAs were not made. Again, employers preferred to remit contributions together with the accrued interests, only when compelled to do so. This is a subtle suggestion that interest penalty for default in remitting contribution is not severe enough. Participation by the organised private sector organisations casts a rather more commendable picture as ever increasing number of them were seen to be switching to the contributory pension scheme.

It is recommended that in order to reverse the current dismal compliance record, actions are required at three levels, namely, individual, labour and regulatory. Individual worker should monitor the state of his RSA by demanding and receiving monthly statement of accounts as provided for by the law. This will help him identify early failure signals to remit contributions. Second, leadership of workers union should engage employers on the need for regular remittance of contributions and procurement of appropriate insurance covers. This is with a view to ensuring that the future financial security of its members is guaranteed. Since insurance cover is an annual contract, it is proper for labour leadership to monitor the renewal status of insurance policies for its members. Finally, the pension regulator should not only closely monitor compliance but must push for a review of the 
penalty for default in remittance. A penalty provision that will make compliance more compelling is here recommended.

\section{Conflicts of Interest}

The authors declare no conflicts of interest regarding the publication of this paper.

\section{References}

Akin-Fadeyi, T., \& Prochazka, J. (2016). Financial Inclusion in Nigeria: Trends, Achievements, Challenges and Prospects. Bullion, (1-40), 89-100.

Bello, S. (2018). Minimum Wage: N30000 Monthly Salary Not Feasible-Presidency. Daily Sun, (15)4045 2.

Binuomoyo, O. K. (2009). The Nigerian Pension System: Reform and Expectations. Pension: An International Journal, 15, 3-10. https://doi.org/10.1057/pm.2009.30

D’Arcy, S. P., Dulebohn, J. H., \& Oh, P. (1999). Optimal Funding of State Employee Pension Systems. The Journal of Risk and Insurance, 66, 345-380. https://doi.org/10.2307/253552

Davis, E. P. (1993). The Structure, Regulation, and Performance of Pension Funds in Nine Industrial Countries. Policy Research Working Paper (1229).

Diamond, P. (1996). Government Provision and Regulation of economic Support in Old Age. In M. Bruro, \& B. Pleskovic (Eds.), Annual World bank Conference on Development Economics (pp. 110-116). Washington DC: The World Bank.

Egbuna, C. (2018). As World Bank Applauds Anambra State. Daily Sun, (15)4045, 17.

Ego-Alowes, J. (2018). NLC Labour Lords. RonuDaily Sun, (15)4064,47.

FGN (2005). Contributory Pension Scheme. A Publication of the Federal Ministry of Information National Orientation.

Gadzama, Z. (2017). FSS 2020: Pension Sector. Bullion, (41)3, 36-38.

Gbolangute, B. (2018). Ondo Pensioners: Our Many Woes. Daily Sun, (15) 4049, 23-24.

Inabo, O. A. (2011). Curbing Financial Wastage in the Public Sector. Sun, 6(2024), 19.

Nweke, M. (2017). N1bn Capitalisation No Longer Adequate for Pension Operators. Daily Sun, (13)3631,23.

Okafor, F. O. (2000). Institutional Aspects of Pension Administration: The Nigerian Experience. Nigerian Journal of Banking and Finance, No. 3, 25-32.

Oloja, M. (2011). Heads May Roll over Alleged Pension Fraud. The Guardian, 28(11610).

Onuorah, M. (2002). Endless Travails of Our Heroes Past. Guardian.

Ovuorie, J. M. (1998). Wanted: A Pension Service Commission (p. 7). Business Time.

Pencom (2016). First Quarterly Report.

Pencom (2017). Fourth Quarterly Report.

Pencom (2018). First Quarterly Report.

The National Assembly (2004). The Pension Reformed Act 2004.

The News (2002). The News Magazine, June, 17. https://doi.org/10.1255/nirn.674

The World Bank (1994). Averting the Income Crisis for the Old. World Bank Policy Research Bulletin, 5, 1-20.

Uche, C. U. (1998). The Adoption of Money-Laundering Law in Nigeria. Journal of 
Money Laundering Control, 3, 220-227. https://doi.org/10.1108/eb027144

Umar, G., \& Emmanuel, T. (2012). Contributory Pension System as a Tool for Economic Development in Nigeria. International Journal of Business and Bebavioural Sciences, 2, 6-8.

Uwujaren, W. (2004). The Looting of Military Pension. Tell, No. 30, 18-23. https://doi.org/10.7748/ns.18.47.30.s45

Uzoh, B. C., \& Anekwe, S. C. (2018). The Contributory Pension Scheme and the Fate of Retired and Retiring Nigerian Workers. International Journal of Academic Research in Business and Social Sciences, 3, 527-541. https://doi.org/10.6007/IJARBSS/v8-i3/3947

Uzoma, P. A. (1993). Pension Schemes in Nigeria. Lagos: Gentle Press Ltd. and Kubay Associates Ltd. 